\title{
Commentary
}

\section{Is intraneuronal amyloid $\beta$-peptide accumulation the trigger of Alzheimer's disease pathophysiology?}

\author{
Paula I. Moreira ${ }^{\mathrm{a}, \mathrm{b}, *}$, Quan Liu ${ }^{\mathrm{a}}$, Kazuhiro Honda ${ }^{\mathrm{a}}$, Mark A. Smith ${ }^{\mathrm{a}}$, Maria S. Santos ${ }^{\mathrm{b}}$ and \\ Catarina R. Oliveira ${ }^{b}$ \\ ${ }^{\mathrm{a}}$ Institute of Pathology, Case Western Reserve University, 2085 Adelbert Road, Cleveland, OH 44106, USA \\ ${ }^{\mathrm{b}}$ Center for Neuroscience and Cell Biology of Coimbra, University of Coimbra, 3004-517 Coimbra, Portugal
}

Using a double mutant transgenic rat model [amyloid precursor $\beta$ protein $(\mathrm{A} \beta \mathrm{PP})$ and presenilin 1 (PS1) mutations], that stably expresses intracellular human amyloid $\beta(\mathrm{A} \beta)$ fragments, Lopez and colleagues [1] report that intracellular $\mathrm{A} \beta$ accumulation in hippocampus and neocortex induces morphological alterations in the Golgi apparatus and lysosomes and an increase in lipofuscin bodies. The authors suggest that the morphological alterations in the Golgi and lysosomes elements may be due to an increased activity of these elements associated with the processing of the high amount of $\mathrm{A} \beta \mathrm{PP}$ present in the brain of the transgenic animals or to an increased activity related with the degradation of oxidative-damaged organelles. Furthermore, the increase in lipofuscin bodies observed by the authors supports the hypothesis of an increase in oxidativedamaged macromolecules. These data raise the issue of whether intracellular $\mathrm{A} \beta$ accumulation or oxidative stress is the trigger of Alzheimer's disease (AD) pathophysiology. Despite the interesting results obtained by the authors, this problem remains unsolved.

Intraneuronal $\mathrm{A} \beta$ accumulation has been directly observed in both human brain tissue and transgenic mice models $[2,3]$ and has been associated with synap-

\footnotetext{
*Corresponding author. E-mail: venta@ci.uc.pt.
}

tic pathology and dysfunction [4,5]. Indeed, previous studies show that transgenic mice containing triple mutations for $\mathrm{A} \beta$, PS1 and $t$, develop defects in longterm potentiation that correlate with the intraneuronal accumulation of $\mathrm{A} \beta$ before the appearance of amyloid plaques [5]. Indeed, in mouse models showing excessive amyloid deposition neuronal loss is modest even though the relative amyloid burden may be far greater than that found in patients with AD [6]. Furthermore, postmortem examination of many cognitively intact elderly individuals often reveals plaque loads above that found in many patients with AD. In addition, in AD the degree of cognitive impairment seems to be correlated with the total $\mathrm{A} \beta$ load rather the plaque load [7].

Several lines of evidence indicated that $\mathrm{A} \beta$ possesses trophic/antioxidant and pro-oxidant/toxic properties that are modulated by redox metal ions. The coordination of copper appears to be crucial for $\mathrm{A} \beta$ 's own antioxidant activity that has been demonstrated both in vitro as well as in the brain, cerebrospinal fluid and plasma [8]. The only known catalytic activity of $\mathrm{A} \beta$ is the dismutation of $\mathrm{O}_{2}^{-} \bullet$ to $\mathrm{H}_{2} \mathrm{O}_{2}$ and tissues will only be protected from subsequent $\mathrm{H}_{2} \mathrm{O}_{2}$-mediated damage when the clearance mechanisms work properly. Thus, excessive accumulation of $\mathrm{A} \beta$-copper may lead to an overproduction of $\mathrm{H}_{2} \mathrm{O}_{2}$ that overwhelm the capacity of defence mechanisms to neutralize it. This would result 
in a feedback loop mechanism that could exacerbate both plaque growth and ROS generation, leading to the functional demise of neurons [9]. Supporting this, one of the earliest pathological events in $\mathrm{AD}$ is oxidative damage to the brains of affected individuals [10]. However, it has been shown that $\mathrm{A} \beta$ deposition is inversely correlated with oxidative damage in AD and Down Syndrome brains [11-14] suggesting that the antioxidant effects of $\mathrm{A} \beta$ outweigh its pro-oxidant actions.

Overall these data indicate that more studies should be performed to identify the initiator event in the complex scenario of $\mathrm{AD}$ and the relative contribution of oxidative stress and $\mathrm{A} \beta$.

\section{References}

[1] E.M. Lopez, K.F.S. Bell, A. Ribeiro-da-Silva and A.C. Cuello, Early changes in neurons of the hippocampus and neocortex in transgenic rats expressing intracellular human $\mathrm{A} \beta, J$. Alzheimers Dis, in press.

[2] Q.X. Li, C. Maynard, R. Cappai, C.A. McLean, R.A. Cherny, T. Lynch, J.G. Culvenor, J. Trevaskis, J.E. Tanner, K.A. Bailey, C. Czech, A. Bush, K. Beyreuther and C.L. Masters, Intracellular accumulation of detergent-soluble amyloidogenic $\mathrm{A} \beta$ fragment of Alzheimer's disease precursor protein in the hippocampus of aged transgenic mice, J. Neurochem. 72 (1999), 2479-2487.

[3] G.K. Gouras, J. Tsai, J. Naslund, B. Vincent, M. Edgar, F. Checler, J.P. Greenfield, V. Haroutunian, J.D. Buxbaum, H $\mathrm{Xu}, \mathrm{P}$. Greengard and N.R. Relkin, Intraneuronal A $\beta 42$ accumulation in human brain, Am. J. Pathol. 156 (2000), 15-20.

[4] R.H. Takahashi, T.A. Milner, F. Li, E.E. Nam, M.A. Edgar, H. Yamaguchi, M.F. Beal, H. Xu, P. Greengard and G.K. Gouras, Intraneuronal Alzheimer $\mathrm{A} \beta$ accumulates in multivesicular bodies and is associated with synaptic pathology, Am. J. Pathol. 161 (2002), 1869-1879.
[5] S. Oddo, A. Caccamo, J.D. Shepherd, M.P. Murphy, T.E. Golde, Kayed, R. Metherate, M.P. Mattson, Y. Akbari and F.M. LaFerla, Triple-transgenic model of Alzheimer's disease with plaques and tangles: Intracellular $\mathrm{A} \beta$ and synaptic dysfunction, Neuron 39 (2003), 409-421.

[6] A.L. Phinney, M.E. Calhoun, D.P. Wolfer, H.P. Lipp, H. Zheng and M. Jucker, No hippocampal neuron or synaptic bouton loss in learning-impaired aged $\beta$-amyloid precursor protein-null mice, Neuroscience 90 (1999), 1207-1216.

[7] J. Naslund, V. Haroutunian, R. Mohs, K.-L. Davis, P. Davies, P. Greengard and J.-D. Buxbaum, Correlation between elevated levels of amyloid $\beta$-peptide in the brain and cognitive decline, JAMA 283 (2000), 1571-1577.

[8] C.S. Atwood, M.E. Obrenovich, T. Liu, H. Chian, G. Perry, M.A. Smith and R.N. Martins, Amyloid- $\beta$ : a chameleon walking in two worlds: a review of the throphic and toxic properties of amyloid- $\beta$, Brain Res. Rev. 43 (2003), 1-16.

[9] A.I. Bush, Metals and neuroscience, Curr. Opin. Chem. Biol. 4 (2000), 184-191.

[10] M.A. Smith, A. Nunomura, X. Zhu, A. Takeda and G. Perry, Metabolic, metallic, and mitotic sources of oxidative stress in Alzheimer disease, Antioxid. Redox Signal 2 (2000), 413-420.

[11] A. Nunomura, G. Perry, K. Hirai, G. Aliev, A. Takeda, S. Chiba and M.A. Smith, Neuronal RNA oxidation in Alzheimer's disease and Down's syndrome, Ann. N. Y. Acad. Sci. 893 (1999), 362-364.

[12] A. Nunomura, G. Perry, M.A. Pappolla, R.P. Friedland, K. Hirai, S. Chiba and M.A. Smith, Neuronal oxidative stress precedes amyloid- $\beta$ deposition in Down syndrome, $\mathrm{J}$. Neuropathol. Exp. Neurol. 60 (2001), 759-767.

[13] A. Nunomura, G. Perry, G. Aliev, K. Hirai, A. Takeda, E. K. Balraj, P.K. Jones, H. Ghanbari, T. Wataya, S. Shimohama, S. Chiba, C.S. Atwood, R.B. Petersen and M.A. Smith, Oxidative damage is the earliest event in Alzheimer disease, $J$. Neuropathol. Exp. Neurol. 60 (2001), 759-767.

[14] M.P. Cuajungco, L.E. Goldstein, A. Nunomura, M.A. Smith, J.T. Lim, C.S. Atwood, X. Huang, Y.M. Farrag, G. Perry and A.I. Bush, Evidence that the $\beta$-amyloid plaques of Alzheimer's disease represent the redox-silencing and entombment of A $\beta$ by zinc, J. Biol. Chem. 275 (2000), 1943919442. 